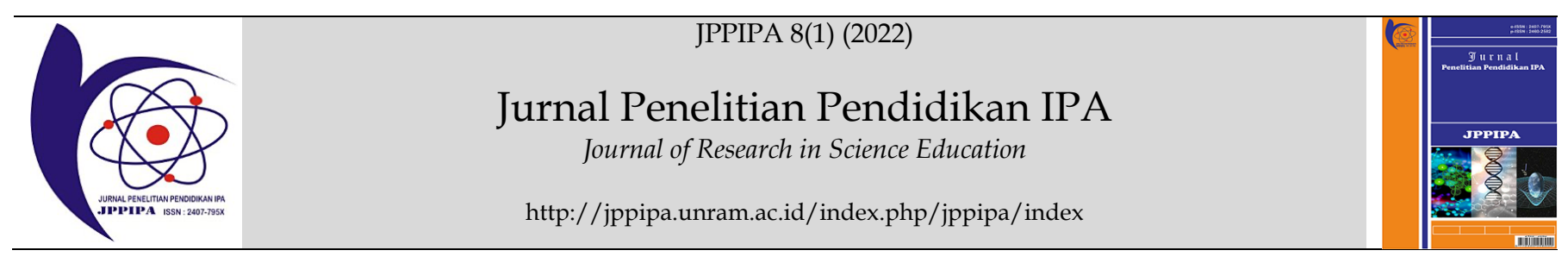

\title{
The Application of the Flipped Classroom Model Integrated with Google Classroom to the Student's Learning Motivation
}

\author{
Rizki Rahma Putri1 ${ }^{1}$ Khairil2, Safrida ${ }^{3 *}$ \\ ${ }^{1}$ Biology Education Study Program, Faculty of Teacher Training and Education, Universitas Syiah Kuala, Banda Aceh, Indonesia
}

DOI: $10.29303 /$ jppipa.v8i1.1157

\section{Article Info}

Received: November 23, 2021

Revised: January 3, 2022

Accepted: January 17, 2022

Published: January 31, 2022

\begin{abstract}
This study aims to determine the differences in students' learning motivation with the application of the flipped classroom combined with the google classroom with conventional methods on the concept of the human circulatory system at MAN 2 Banda Aceh. The method used is quasi-experimental, with a Pretest-Posttest design. The population in this study were all students of class XI IPA MAN 2 Banda Aceh, totaling 120 people. The sampling technique in this study was determined by the purposive sampling technique. The instrument used in this study was a questionnaire. Data analysis used an independent sample t-test. The results showed that there were differences in the application of the flipped classroom combined with the google classroom and the flipped classroom on the motivation for the concept of the human circulatory system at MAN 2 Banda Aceh. Conclusion: the application of the flipped classroom model combined with the google classroom is effective in increasing students' learning motivation compared to using conventional methods.
\end{abstract}

Kata kunci: Flipped classroom model; Google classroom; Motivation

Citation: $\quad$ Putri, R. R., Khairil, K., \& Safrida, S. (2022). The Application of the Flipped Classroom Model Integrated with Google Classroom to the Student's Learning Motivation. Jurnal Penelitian Pendidikan IPA, 8(1), 263-268. https://doi.org/10.29303/jppipa.v8i1.1157

\section{Introduction}

Learning motivation includes abilities that must be possessed by every student, with high motivation students will gain enthusiasm in the learning process. Without good learning motivation, it will affect the learning objectives to be achieved (Harsel, et al., 2019).

Based on the results of observations and interviews with biology teachers at MAN 2 Banda Aceh in June 2020 that, in biology learning, especially the material for the human circulatory system, students are still passive in asking questions and answering questions from problems posed by the teacher, and lack of ideas. or problem-solving ideas. Many students get scores below the minimum completeness criteria set by the school, which is 75 . The data obtained is only $55 \%$ of students who score above the minimum completeness criteria in the human circulatory system material. The lack of students' learning motivation has an impact on the value of learning outcomes.
Developing students' motivation and learning outcomes requires an appropriate learning strategy and media. One of them is by using Flipped Classroom learning. Flipped Classroom is a teaching and learning process that is not like in general, namely in the learning process students learn subject matter at home before class starts and teaching and learning activities in class are in the form of doing assignments, discussing material or problems that students have not understood. The application of the flipped classroom learning model is effective in improving critical thinking skills, learning outcomes and learning motivation, there is a positive influence between learning motivation and critical thinking skills and student learning outcomes (Kurnianto, et al., 2020). The flipped classroom model helps students to learn at their own pace, encourages students to be actively involved with lecture material, frees up actual class time for more effective, creative and active learning activities, teachers receive expanded opportunities to interact with and assess student 
learning, and students take control and responsibility for their learning (Gilboy, et al., 2015).

Flipped classroom learning in this study is combined with Google classroom media. Google classroom is a learning medium that can be used by teachers and students to create virtual classes, teachers can provide materials and assignments to participants which are received in real time by students (Izenstark and Katie, 2015).

Google Classroom media is an application provided by Google for Education to create an online classroom system that is used not only on the website but also on smartphones. Google classroom is very easy to do, assigning assignments saves time, teaching materials can still be accessed even though students are no longer in class. The google classroom application aims to help create active, effective, efficient and fun learning.

Several studies on research on Flipped Classroom learning have been conducted (Munir, 2018; Damayanti, 2016; Subagia, 2017; Pratiwi, 2021). The results of these studies only reveal the application and use of Flipped Classroom to improve learning outcomes, student learning activities, study the influence of Flipped Classroom learning combined with Google Classroom media on motivation and learning outcomes is still limited. Therefore, this research is important to do to answer the question of whether the effect of flipped classroom learning combined with Google classroom on motivation and learning outcomes of students on the material of the human circulatory system.

The Flipped classroom model combined with Google classroom was applied to the experimental class and the control class using the Flipped classroom model. This study aims to determine the differences in students' learning motivation with the application of the flipped classroom combined with the google classroom with conventional methods on the concept of the human circulatory system at MAN 2 Banda Aceh.

The hypothesis in this study, there are differences in students' learning motivation with the application of the flipped classroom combined with the google classroom with conventional methods on the concept of the human circulatory system at MAN 2 Banda Aceh. The benefit of the results of this study is to increase students' learning motivation by using the Flipped Classroom Model combined with Google Classroom.

\section{Method}

This research was conducted at MAN 2 Banda Aceh. The research was conducted in the odd semester of the 2020/2021 Academic Year. The approach applied is quantitative. This type of research is quasiexperimental and uses applied methods to determine the intervention that arises according to treatment in the experimental variable. The treatment of the 2 experimental and control groups was to test the impact of the treatment used on learning. The stages of the research are (1) giving a pre-test of motivation, (2) applying treatment using the Flipped classroom model combined with Google classroom in the experimental group and using the Flipped classroom model in the control group, and (3) providing a post-test of learning motivation for both classes.

This design will compare the pre-test and post-test scores of the experimental class and the control class. The design used in this study is the Pretest-Posttest Control Group Design, which is in Table 1.

Table 1. Pretest-Posttes Control Group Design

\begin{tabular}{|c|c|c|c|}
\hline Classes & Pre-test & Treatment & Post-test \\
\hline Experiment & $\mathrm{O}_{1}$ & $\mathrm{X}_{1}$ & $\mathrm{O}_{2}$ \\
\hline Control & $\mathrm{O}_{3}$ & $x$ & $\mathrm{O}_{4}$ \\
\hline \multicolumn{4}{|c|}{ Description: } \\
\hline $\mathrm{X}_{1}$ & \multicolumn{3}{|c|}{$\begin{array}{l}\text { Treatment of the application of the } \\
\text { Flipped classroom model combined with } \\
\text { Google classroom }\end{array}$} \\
\hline$X$ & \multicolumn{3}{|c|}{ Using the Flipped classroom model } \\
\hline $\mathrm{O}_{1}$ & \multicolumn{3}{|c|}{ Pretest results in the experimental class } \\
\hline $\mathrm{O}_{2}$ & \multicolumn{3}{|c|}{$\begin{array}{l}\text { Final posttest results in the experimental } \\
\text { class }\end{array}$} \\
\hline $\mathrm{O}_{3}$ & \multicolumn{3}{|c|}{ Pretest results in the control class } \\
\hline $\mathrm{O}_{4}$ & \multicolumn{3}{|c|}{ Final posttest results in the control class } \\
\hline
\end{tabular}

The population in this study were all students of class XI IPA MAN 2 Banda Aceh with a total of 90 people. The sampling technique in this study was determined by the purposive sampling technique. The sample in the experimental class is 30 people and the control class is 30 people. Determination of samples of the experimental class and control class by looking at the standard deviation of the results of the pretest of homogeneous students (the ability of homogeneous students). Questionnaire instruments to measure students' motivation in learning by using motivation questionnaires are attention, relevance, confidence, and satisfacion (ARCS) by John Keller. The implementation of this research is completed with instruments including; Learning Program Plans and Student Worksheets.

Questionnaire processing is carried out by scoring for all choices on each question where each choice in the statement has a different score, then the scores are added up for each indicator and the score is searched with equation 1.

Avarage score $=\frac{\sum \text { acquisition score }}{\sum \text { statement }} \ldots \ldots \ldots \ldots \ldots . . . . .(1)$ Source: (Keller, 2000) 
Table 2. ARCS Motivasi Motivation Score

\begin{tabular}{lcc}
\hline \multirow{2}{*}{ Criteria } & \multicolumn{2}{c}{ Score } \\
\cline { 2 - 3 } & $\begin{array}{c}\text { Positive } \\
\text { Statement }\end{array}$ & $\begin{array}{c}\text { Negative } \\
\text { Statement }\end{array}$ \\
\hline Strongly Agree (SA) & 5 & 1 \\
Agree (A) & 4 & 2 \\
Less Agree (LA) & 3 & 3 \\
Disagree (DA) & 2 & 4 \\
Strongly Disagree & 1 & 5 \\
(STS) & & \\
\hline
\end{tabular}

From the results of the calculation of the questionnaire data of all students on the measurement of students' motivation in the teaching and learning process in the classroom, it will obtain a percentage value, which can be transformed into determining the percentage scale benchmark. The results obtained were interpreted using the criteria presented in Table 3.

Table 3. Classification of Students' Learning Motivation Scores

\begin{tabular}{ll}
\hline Score & Category \\
\hline $86-100$ & Verry Good \\
$76-85$ & Good \\
$60-75$ & Enough \\
$55-59$ & Less \\
$\leq 54$ & Verry less \\
\hline
\end{tabular}

The stages of data analysis are: 1) normality test with the Kolmogorov-Smirnov test, the criteria for the value of Sig. $>0.05$ then the data is declared normal, 2) homogeneity test using the Levene test, 3) independent sample t-test. To do this test, use SPSS version 21 . Independent Sample t-test test criteria if $(p<0.05)$ then there is a difference in students' learning motivation.

\section{Result and Discussion}

The results of data collection consisted of students' learning motivation on the material of the human circulatory system at MAN 2 Banda Aceh after the Flipped classroom was implemented combined with Google classroom obtained in the form of pretest and posttest scores. The paired sample t-test was used to see the difference in students' learning motivation before and after learning with the application of the Flipped classroom combined with Google classroom material on the human circulatory system at MAN 2 Banda Aceh.

The average increase in each indicator of students' learning motivation on the material of the human circulatory system consisting of four namely attention, relevance, belief, satisfaction, can be seen in Figure 1.

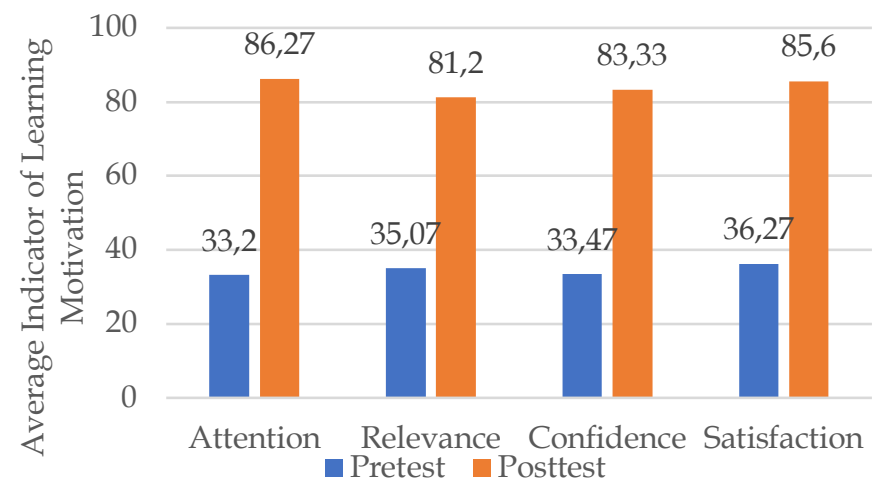

Figure 1. Average Indicators of Learning Motivation of Experimental Class Students

The results showed that the application of Flipped Classroom combined with Google Classroom could increase students' learning motivation at MAN 2 Banda Aceh. Students' learning motivation after participating in learning using Flipped Classroom combined with Google classroom on the attention indicator shows a pretest value of 33.2 and posttest 86.27 , this shows that students feel that at the beginning of learning there is something that catches their attention, students feel that by giving a problem through a video given by the teacher to students so that curiosity becomes aroused and they focus on working on learning activities on the material of the circulatory system.

This is in accordance with Keller (2010), attention is a form of direction to be able to concentrate or focus on dealing with students in events during the teaching and learning process in class. Attention can mean the same as concentration, can also show interest, namely the feeling of being interested in a problem that is being studied. Animated videos also provide a more real understanding of student learning (Ritonga, et al., 2020). In addition, Google Classroom makes teaching and learning activities more productive and meaningful by simplifying tasks, increasing collaboration, and fostering communication between students and teachers (Atikah, et al., 2021).

The relevance indicator (relevance) shows a pretest value of 35.07 and posttest 81.20 , it shows that students feel that the provision of information is in accordance with their learning interests and they believe they can know what to learn in the material of the human circulatory system. This is in line with Lahagu (2010) which states that good learning is learning that involves students in learning activities and helps them relate academic lessons to the real-life contexts they face.

The self-confidence indicator shows a pretest score of 32.6 and a posttest of 73.64, it shows that students can express questions and answers in class. This is in accordance with Keller (2010), the attitude of someone who feels confident, believes that they can succeed in 
achieving something will affect them in behaving to achieve that success. Students who have a confident attitude have a positive assessment of themselves tend to display good achievements continuously.

The satisfaction indicator shows the pretest value of 36.27 and posttest 85.60 , meaning that the application of Flipped Classroom combined with Google Classroom has a very good impact on motivating students' learning, stimulating students' curiosity so that when students are able to work on and solving a problem and the problem is solved by himself will create a sense of pride and satisfaction in his heart so that learning the circulatory system in humans is memorable and very easy to learn. According to Keller (2010), the intended satisfaction is a feeling of joy, this feeling can be positive, that is, it arises when people get an appreciation for themselves. Confidence generation occurs when the teacher says "good", when students answer or ask questions. Reinforcement that can give students a sense of pride and satisfaction is important and necessary in learning activities.

There are four aspects that must be met by educators when implementing flipped learning in class. Look at the Figure 2.

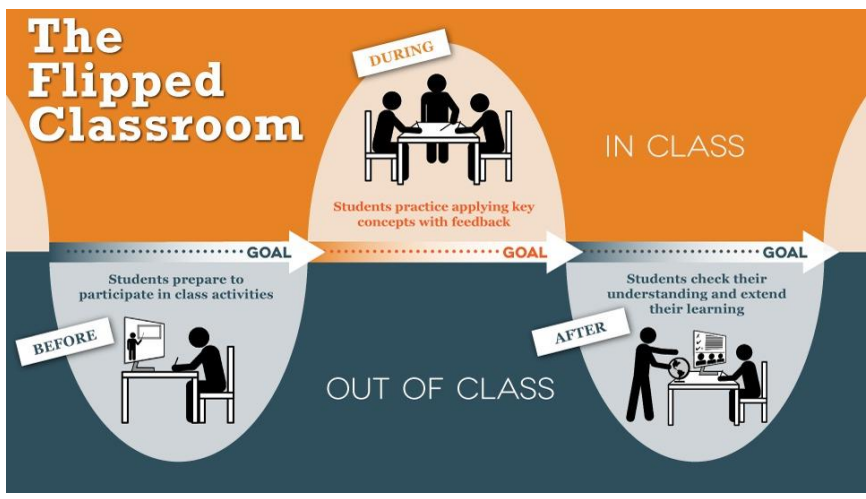

Figure 2. Schema Flipped Classroom Model

The results revealed that most of the students had a positive attitude towards the flipped classroom and it was highly correlated with perceptions of increased motivation, engagement, increased learning, and effective learning (Nouri, 2016). In line with the opinion of Daniati, et al (2020) explaining the application of google classroom can increase students' learning motivation.

In the control class applied using conventional methods. The average increase in indicators of students' learning motivation in the control class is presented in Figure 3.

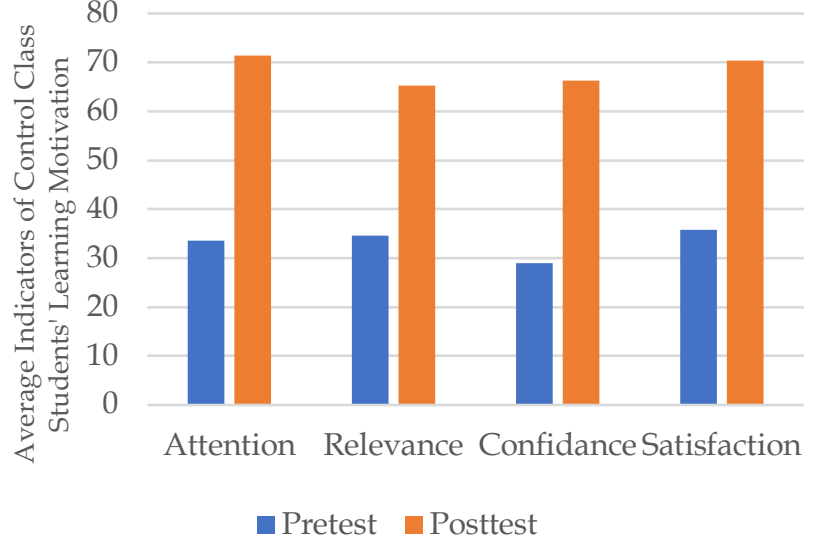

Figure 3. Average Indicators of Control Class Students' Learning Motivation

Students' learning motivation uses conventional learning, students feel bored with teacher-centered learning methods without any element of student activity in the ongoing process of teaching and learning activities in the control class. In addition, conventional learning does not provide opportunities for students to gain their own knowledge about environmental pollution material so students are less motivated in learning.

The results of the independent sample t-test pretest student motivation at MAN 2 Banda Aceh, can be seen in Table 4.

Table 4. Results of Independent Sample T-test Posttest Students' Learning Motivation

\begin{tabular}{|c|c|c|c|}
\hline Class & Normality*) & Homogenity**) & Significant**) \\
\hline \multirow{2}{*}{$\begin{array}{l}\text { Control } \\
\text { Experimen }\end{array}$} & Sig, 0.064 & Sig, 0.051 & $\mathrm{t}_{\text {caunt }}: 13.02>$ \\
\hline & Sig, 0.200 & & $\begin{array}{l}\mathrm{t}_{\text {table: }}: 1.67 \\
\rho<.001\end{array}$ \\
\hline *) & Kolmogoro & Smirnov $(\rho \geq a$ & ,05) \\
\hline$* *)$ & rene test $(\rho \geq$ & $x 0,05)$ & \\
\hline ***) & ependen Sa & pel T-tes & \\
\hline
\end{tabular}

Based on Table 4. shows the results of the independent sample t-test of the test students' learning motivation obtained $(\rho<.001)$ then Ha is accepted, so it is concluded that there are differences in students' learning motivation between the control class and the experimental class on the material of the human circulatory system MAN 2 Banda Aceh. The application of flipped classroom combined with google classroom showed significantly better learning motivation compared to students who followed the conventional method on the human circulatory system material at MAN 2 Banda Aceh.

There is a difference in learning motivation for the experimental class and the control class due to the treatment of the flipped classroom model combined with google classroom helping students read the 
material, watch videos on the human blood circulatory system material before they come to class and they start discussing, exchanging knowledge and solving problems. In line with the opinion of Brent (2013), the flipped classroom is a learning model by minimizes the amount of direct instruction but maximizes one-on-one interaction. This strategy utilizes technology that supports additional learning materials for students that can be accessed online and offline whenever and wherever. While learning time in class is used by students to collaborate with project partners, practice skills, and receive feedback on student progress.

The results of the average pretest and posttest learning motivation of the control class and the experimental class to see the difference in the average learning motivation of students can be seen in Figure 4.

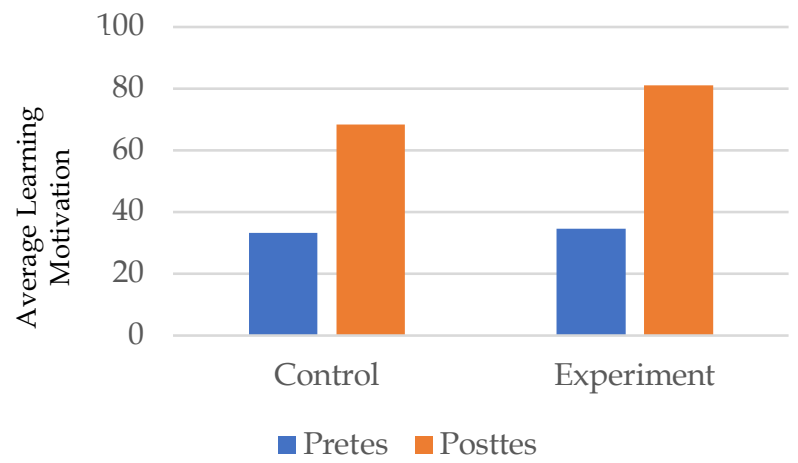

Figure 4. Average of Pretest and Posttest Students' Learning Motivation in Control Class and Experiment Class

Figure 4. shows the average difference in participants' learning motivation between the control class and the experimental class. The posttest mean of learning motivation in the control class is 68.36 and the experimental class is 81.10 . Based on the average obtained in the control and experimental groups, it can be seen that the average learning motivation of students in the experimental group is greater than the control group. This can be interpreted that student who take part in flipped classroom learning combined with google classroom show significantly better student motivation compared to students who follow the google classroom method on the material of the human blood circulation system at MAN 2 Banda Aceh.

The application of flipped classroom combined with google classroom emphasizes the learning process to make it easier for students to understand participants by repeating the material and asking for parts of the material that have not been understood by students. In line with the opinion (Fulton, 2012) the application of the flipped classroom model helps students to follow the lesson according to the speed of their understanding because there is an opportunity to repeat the material if needed, homework is completed in class and students can ask parts that have not been understood, students have the opportunity to access learning in full, learning time in class is used effectively by teachers and students, teachers who apply flipped classroom get higher results than implementing traditional learning.

The application of the flipped classroom model has a better effect on student learning outcomes than the direct learning model (Igirisa, 2017). Research by Yanuarto (2018) also supports this model where there is an increase in the quality of learning through flipped classrooms, increased learning independence, and the use of technology in flipped classroom learning also has a positive impact on the role of technology in education. Thus, it can be concluded that the flipped classroom is a model that combines online learning at home and faceto-face in the classroom with the integration of technology in it. The results showed that there were differences in the learning motivation of students in the experimental class and the control class (Hasanah, et al, 2021).

\section{Conclusion}

There are differences in the learning motivation of students who are taught using the flipped classroom model combined with google classroom and conventional methods on the human circulatory system material at MAN 2 Banda Aceh. The application of the flipped classroom model combined with google classroom is more effective in increasing learning motivation than conventional methods.

\section{References}

Atikah, R. Prihatin, R. T, Hernayati, H. \& Misbah, J. (2021). Pemanfaatan Google Classroom Sebagai MediaPembelajaran Di Masa Pandemi Covid-19. Jurnal Petik: 7(1). https://doi.org/10.31980/jpetik.v7i1.988

Brent, G. (2013). Student Perceptions Of The Flipped Classroom. Columbia: The University Of British Columbia

Damayanti, H. N., \& Sutama, S. (2016). Efektivitas Flipped Classroom Terhadap Sikap dan Keterampilan Belajar Matematika di SMK. Manajemen Pendidikan, 11(1):2-7. https://doi.org/10.23917/jmp.v11i1.1799

Daniati, Bambang, I. Dwi, I. L. (2020). Upaya Peningkatan Motivasi dan Hasil Belajar Mahasiswa dengan Penerapan Model Pembelajaran ELearning Berbasis Google Classroom pada Masa Pandemi Covid-19. Jurnal Hasil Penelitian dan Kajian Kepustakaan di Bidang Pendidikan, Pengajaran dan Pembelajaran, 6(3). 601-608. https://doi.org/10.33394/jk.v6i3.2642 
Fulton, K.P. (2012). 10 reasons to flip, The Phi Delta Kappan, 94(2). 20-24. http://dx.doi.org/10.2307/41763589

Gilboy, M. B., Heinerichs, S., \& Pazzaglia, G. (2015). Enhancing student engagement using the flipped classroom. Journal of nutrition education and behavior, 47(1).

109-114. https:// doi.org/10.1016/i.jneb.2014.08.008

Hamdan, Noora., McKnight, Patrick., McKnight, Kathrine. \& Arfstrom, Kari M (2013). A White Paper Based on The Literature Review Titled: Review of Flipped Learning. London: Pearson

Harsel, M. V., Hoogerheide, V., Verkoeijen, P., \& Gog, T. V. (2019). Effects Of Different Sequences Of Examples And Problems On Motivation And Learning. Contemporary Educational Psychology. 58(0).

260-275. https://doi.org/10.1016/j.cedpsych.2019.03.005

Hasanah, Z. Ritonga, S. Ikhsan, Z. \& Suarni. (2021). The Implementation of Problem Based Learning Integrated with STEM Based Worksheets to Improve Learning Motivation. Asian Journal of Science Education, (3)2. 102-112. https://doi.org/10.24815/ajse.v3i2.19745

Igirisa, N. (2017). Pengaruh Model Flipped Learning Terhadap Hasil Belajar Matematika Ditinjau dari Gaya Belajar Siswa. Jurnal Riset dan Pengembangan Ilmu Pengetahuan, 02(1). 80-84. Retrieved from http://ejurnal.pps.ung.ac.id/index.php/JPS/artic le/view/119

Izenstark, A. \& Katie L.L. (2015). Google Classroom for Librarians : Features and Opportunities. Library Hi Tech News. $\quad 32 \quad$ (9). 1-3. https://doi.org/10.1108/LHTN-05-2015-0039.

Johnson, Graham Brent. (2013) Student Perceptions of The Flipped Classroom. Tesis. Okanagan: Educational Technology the University of British Columbia

Keller, J, M. (2010). Motivational Design for Learning and Performance: The ARCS Model Approach. New York: Springer

Kurnianto, B., Wiyanto, \& Sri, H. (2020). Critical Thinking Skills and Learning Outcomes by Improving Motivation in the Model of Flipped Classroom. Journal of Primary Education, 9(3):282291.Retrieved

from https://journal.unnes.ac.id/sju/index.php/jpe/ar ticle/view/27783

Lahagu, N., Ibnu, S. \& Subandi. (2010). Meningkatkan Motivasi dan Hasil Belajar Kimia melalui Pembelajaran Kooperatif Tipe STAD dan Problem Solving. Jurnal Sains, 39 (1). 50-58. Retrieved from http://mulok.library.um.ac.id/index3.php/42774. $\underline{\mathrm{html}}$

Maria, J. Ferrer, C. Miralles, P. \& Martínez. (2021). Effectiveness of the flipped classroom model on students' self-reported motivation and learning during the COVID-19 pandemic. Humanities And Social Sciences Communications, 8(176). 1-6. https://doi.org/10.1057/s41599-021-00860-4

Munir, M. T, Baurotian, S., Young, B.R., \& Carter, S. (2018). Flipped classroom with cooperative learning as a cornerstone. Education for Chemical Engineers, 23(4), $25-33$. https://doi.org/10.1016/j.ece.2018.05.001

Nouri, J. (2016). The flipped classroom: for active, effective and increased learning - especially for low Achievers. International Journal of Educational Technology in Higher Education, 13(33). 1-6. https:// doi.org/10.1186/s41239-016-0032-z

Pratiwi, R. (2021). Pengaruh Model Flipped Classroom Terhadap Hasil Belajar Ditinjau dari Gaya Belajar peserta didik pada Mata Pelajaran Ekonomi di SMA Negeri 1 Indralaya. Skripsi. Akultas Keguruan dan Ilmu Pendidikan. Universitas Sriwijaya

Ritonga, S., Safrida, S., Huda, I., Supriatno, \& Sarong, M. A. (2020). The effect of problem-based video animation instructions to improve students' critical thinking skills. Journal of Physics: Conference Series, 1460(1). 1-6. http://dx.doi.org/10.1088/17426596/1460/1/012107

Sirakaya, D \& Selcuk, O. (2018). The Effect of a Flipped Classroom Model on Academic Achievement, SelfDirected Learning Readiness, Motivation and Retention. Malaysian Online Journal of Educational Technology, 6(1). 76-91. Retrieved from https://eric.ed.gov/?id=EJ1165484

Subagia, M. (2017). Flipped Classroom sebagai Meningkatkan Hasil Belajar siswa dan aktifivitas belajar siswa. Journal Program Pascasarjana Universitas Pendidikan Ganesha Program. 4(3).

Yanuarto, W. N. (2018). Flipped Classroom Learning Model untuk Menumbuhkan Kemandirian Belajar Matematika dan Memaksimalkan Peran Teknologi pada Pendidikan. Jurnal Pendidikan Matematika, 1(1).

13-19. https://doi.org/10.36277/defermat.v1i1.10

Yulietri, F., \& Mulyoto, M. (2015). Model Flipped Classroom dan Discovery Learning Pengaruhnya Terhadap Prestasi Belajar Matematika Ditinjau Dari Kemandirian Belajar. Jurnal Teknodika, 13(2). 9-16. Retrieved from https://jurnal.fkip.uns.ac.id/index.php/teknodik a/article/view/6792 